\title{
Birds in New York State Have Altered Their Migration Timing and Are Experiencing Different Thermal Regimes While Breeding or on Stopover from 2010 to 2015
}

\author{
Natalie Pudalov, Sydney Ziatek, and Ana Gabriela Jimenez \\ Biology Department, Colgate University, 13 Oak Dr., Hamilton, NY, USA \\ Correspondence should be addressed to Ana Gabriela Jimenez; ajimenez@colgate.edu
}

Received 5 May 2017; Revised 26 June 2017; Accepted 11 July 2017; Published 19 September 2017

Academic Editor: Hynek Burda

Copyright (c) 2017 Natalie Pudalov et al. This is an open access article distributed under the Creative Commons Attribution License, which permits unrestricted use, distribution, and reproduction in any medium, provided the original work is properly cited.

\begin{abstract}
Migration represents a significant physiological challenge for birds, and increasing ambient temperatures due to global climate change may add to birds' physiological burden during migration. We analyzed migration timing in a central New York county and two counties in the Adirondack region by using data from the citizen science network, eBird, and correlating it with historical temperature data. Species of birds sighted in Central NY $(N=195)$ and the Adirondack region $(N=199)$ were categorized into year-round residents and one- and two-stopover groupings based on eBird observations. Using linear regressions, we looked at various relationships between temperature and variables relating to birds' migration across 2010-2015. Of the total 195 species used within this data in Central NY, 35 species showed some alteration in their migration timing or in the temperature regime they experienced while breeding or on migration stopover. In the Adirondack region, of the total 199 species used within this dataset, 43 species showed some alteration in their migration timing or experienced significantly colder or warmer temperatures while breeding or on migration stopover during 2010-2015. Additionally, many of the bird species affected by temperature changes in the state of New York and those that altered migration timing tended to be long-distance migrants.
\end{abstract}

\section{Introduction}

The commonly accepted notion is that the current rapid climate warming will exacerbate the frequency and intensity of heat wave events, which, in turn, selects for increased thermal tolerance in animal populations [1-3]. A critical task for scientists, then, is to identify characteristics of species that will make them either physiologically susceptible or resilient to increases in air temperature [3]. Temperature is of critical importance when determining factors affecting energy and water balance for all animals; thus, climate change has the potential for severely affecting fitness, life-history trade-offs, and physiology of many species [3]. In the decades to come, if animals are to survive and thrive while dealing with increasing ambient temperatures, they will need to alter their distribution patterns, change their behavioral patterns, and/or adjust their physiology to compensate for increasing thermal demands [2-4]. At worst, if evolutionary or plastic adjustments are impossible or slower than the rate required to keep up with environmental change, the mismatch between physiological capacities and environmental variation will lead to local extinction [5].

A widely studied phenomenon in global climate change has been the relationship of changes in temperatures with regard to bird phenology, particularly in terms of earlier timing of spring migration, earlier breeding, and earlier singing of some birds (e.g., [6]). In spring, temperature determines when food becomes available in temperate latitudes [7]. An early arrival during spring migration to breeding grounds can improve fitness when birds are able to establish better breeding territories, increasing chances of finding a mate or a better quality mate, improving the probability of laying several clutches, and providing accessibility to better environmental conditions to raise offspring $[8,9]$, whereas a delayed arrival compared with the rest of the population may mean reduced reproductive output, loss of mating opportunities, and decreases in breeding time [8]. These options present the potential of an ecological mismatch if birds leave too 
early and arrive to breeding grounds before cold temperature subsides, or, alternatively, if they leave too late and, thus, miss reproductive opportunities [10]. Fall migration poses similar problems with respect to resources: those birds that arrive to stopover sites earlier have better choices among resources to refuel or breed, whereas those who arrive later may face depleting resources and harsher weather conditions $[9,11]$. The ability to be flexible around migration allows migrants to avoid harsh environmental conditions and take advantage of resources as they become available [7].

Individual migration plasticity, in terms of arrival and departure dates, seems to be the mechanistic explanation as to why some species are able to alter their spring arrival dates and fall departure dates [8, 12]. Generally, timing of migration is said to be adjustable prior to departure when physiologically challenging environmental conditions pose additional threats to the bird, or it can be altered mid-migration when improved environmental conditions at stopover sites can reduce the time required to refuel [13]. However, timing of migration can be further complicated by effects of climate change, weather en route, and population declines, as well as the rate at which birds can refuel during stopover $[14,15]$. Migratory strategy, that is, whether a species is short or long-distance migrant, is said to be a strong predictor of alteration in migration [16]. Short-distance migrants spend winters close to breeding grounds and may be better suited to determine conditions of their preferred breeding sites, adjusting the timing of their migration appropriately, whereas, long-distance migrants seem to undergo migration when cued endogenously, rather than basing their departure on environmental cues [12]. Thus, species that migrate for shorter distances may be better able to adjust their arrivals to a greater extent than long-distance migrants [16]. Additionally, we have evidence that those bird species that have not shown phenological responses to increases in mean global temperatures tend to be long-distance migrants [10] and have shown population declines, likely due to increases in mistiming of reproduction $[17,18]$. Furthermore, detectability for changes in migration timing can also be affected by population size, so that larger populations should show earlier detection [19].

An increase in ambient temperature due to global climate change also poses physiological challenges for nonmigrants, who remain in areas with these altered temperatures yearround $[4,20]$. Average temperature variation per state over the past 100 years in the New England-New York region is increasing, from $0.86^{\circ} \mathrm{C}$ to $1.86^{\circ} \mathrm{C}$, making New York State the 8th fastest warming state in the United States [21, 22]. Thus, considering bird migratory timing through the state of New York is of importance to determine (1) species that have altered the timing of migration and (2) how long birds that are breeding or migrating through NY are staying, as well as establishing what temperatures they are experiencing during their stay. The novelty of our study falls on the fact that we were interested in thermal regime changes once birds arrived to breeding ground or stopover sites. Thus, we determined (3) whether recently arrived or departing species are experiencing significantly different temperature regimes than they normally would. This is of importance because migrating birds undergo an extreme physiological challenge that may be further exacerbated by temperature extremes.

\section{Materials and Methods}

2.1. Using eBird Data. Although citizen science is often associated with certain implicit negative biases, for example, the supposed lack of accuracy, validity, or reduced or absent personnel training when compared with the traditional academic system, the scientific community has recently embraced some of the strengths of this method of data collection, including the ease and speed with which wide-ranging data can be gathered [24]. The rapid changes in climate have spurred significant interest from both the scientific community and private citizens in documenting ecological and organismal responses to this phenomenon, and the realities of documenting the expansive issue of climate change belie the crux of the change in scientific attitudes towards citizen science. Scientists, now, have access to otherwise unattainable, large, and spatial datasets through citizen science databases, which have proven crucial in determining range shifts and distributional patterns alterations in many species, especially with respect to birds [25].

The citizen science database eBird works hard to decrease the negative bias associated with citizen science. Humans are the sole best computational method to identify any species due to organisms' phenotypic intricacies and behavior, and fortunately, birders make a pastime out of identifying and cataloguing bird species across our planet [26]. eBird is the most popular data repository used by avid birders who are adept at correctly identifying species [26]. Committed, repeated users, termed "power users," submit the majority of data, which helps to maintain high quality data on the site [26]. Additionally, eBird enhances the participants' experience while using the site or the app, by educating users on best practices and methods while birding, and they also provide virtual incentives to reward participants for following rigorous protocols while collecting data [26]. Lastly, regional editors monitor submissions to increase the integrity and accuracy of the data, identifying those submissions that are either unlikely or unverified $[26,27]$. eBird is a major source of avian biodiversity data, now being used across many disciplines [27]. Over the last 5 years, $\sim 80$ publications have been published in peer-reviewed journals using data gathered through eBird (http://ebird.org/content/ebird/about/publications/). Though eBird observations from citizen scientists are submitted throughout the year, participants are particularly active during the spring and fall migration, and thus the data from these seasons is particularly suitable for the examination of migration timing with respect to changing environmental temperatures $[25,28]$.

2.2. Choice of Year Range and Counties. Prior to 2010, there were many observational gaps in the eBird data for the majority species listed in both Madison County and the Adirondack region. Thus, while using data from 2010 to 2015 seems like a small sample size, we selected those years to 
ensure that we were encapsulating the best data available for this area. Additionally, organismal adaptations are driven by selective pressures on a phenotype and 2010-2015 marked the most notable increases in temperature ever recorded, thus, demonstrating a strong phenotypic pressure for birds to adjust migration strategies and/or physiology [14]. We chose the three counties with the highest observation frequencies for their respective regions in New York State: Madison County for Central NY and Franklin County and Essex County for the Adirondack region. We downloaded all reported observations from Madison, Franklin, and Essex counties from 2010 to 2015 from eBird and further cleaned the data and categorized bird species following the criteria below. Franklin and Essex County data was combined to allow us to look at migration timing and thermal regimes through the Adirondack region.

2.3. Data Cleaning. After we downloaded all of the observations for birds within these three counties, we cleaned the data by removing any bird species that were listed as a "hybrid" or included a " $\mathrm{x}$ " or "/" within its name, which indicated inaccuracies in the sightings. Additionally, any bird species that did not have at least 5 years' worth of data was also eliminated from our analysis. Though citizen science has its limitations, our manual cleaning of the data reduces some of the noise and inaccuracies associated with these data sets.

2.4. Classifications. Species of birds sighted in Madison County ( $N=195$ after cleaning) and the Adirondack region ( $N=199$ after cleaning) were categorized into year-round resident, one-stopover, and two-stopover groupings based on eBird observations. Birds with unclear timing were crosschecked with literature $[29,30]$ and birds with undefinable migration timing were simply removed from the analysis. We use the term "one-stopover species" to describe migratory species that spent their summer breeding season in the study counties. Furthermore, we use the term "two-stopover species" to describe those that breed north of the study counties and pass through during both spring and fall migrations. Species were also categorized by migration strategy, short, medium, or long-distance migrants. We define these terms according to [31], where short-distance migrants traveled less than $2000 \mathrm{~km}$ and long-distance migrants traveled over $2000 \mathrm{~km}$. Short-distance and long-distance categories were determined using data from the Cornell lab of Ornithology and Zuckerberg et al. [23].

2.5. Temperature Data. We used the years of 2010-2015 partially due to the record breaking average high temperatures during these years and partially because this was the range of dates in which eBird observations were the most complete and representative. The Adirondack region was observed to be warming faster than central New York (IPCC 2013), making this an interesting comparison for migratory birds across New York State. Historical temperature data was collected from weather underground (https://www.wunderground.com). We correlated daily minimum, maximum, and mean temperatures for arrival dates and departure dates. Furthermore, we correlated minimum, maximum, and mean temperatures for the time spent in each county (averages across the number of days spent in the county). For Madison County, we used data from the weather station in Rome, NY, and for the Adirondacks region counties we used the data from the weather station in Saranac Lake, NY.

2.6. Analysis and Linear Regressions. After cleaning the data, we first analyzed whether spring (arrival) and fall (departure) migration dates were shifting across 6 years for $(N=195)$ species in Madison County and $(N=199)$ species in the Adirondack region, and whether total number of days spent in each county by a bird species changed from 2010 to 2015 . We, then, examined how arrival and departure dates as well as total days in one county related to temperature across 6 years.

We used first-observed arrival dates from the downloaded eBird data because, while migration plasticity may eventually be a population-wide phenomenon, it has been established that population-level advances in migration are ultimately dictated by individuals advancing or delaying migration [8, 12, 14]. We also used last seen dates from our cleaned eBird data to determine departure dates. Daily temperatures on arrival and departure date were not used to predict migration advancement; rather, they were used to assess whether birds would be further physiologically challenged by significantly colder or hotter temperatures after migration.

We examined 14 relationships between temperature and migration for one-stopover birds for each county, including arrival and departure date and mean, minimum and maximal temperature for that date, time spent in the county, and temperature experienced while in that county. For two-stopover birds, we examined 15 relationships for bird species migrating through these counties in the spring and 15 relationships for bird species migrating through these counties in the fall, including similar correlations as those stated above for one stopover species (Figure 1). For year-round birds, we analyzed the maximum, minimum, and mean temperatures experienced through each of the 6 years included in our dataset. Linear relationships were considered significant if $p<0.1$ and we used SPSS statistics program version 24 . We, further, corrected for the large number of comparisons by using a Bonferroni correction. Our $p$ values after the Bonferroni correction were $p \leq 0.007$ for one-stopover species, which included 14 linear regressions per specie, and $p \leq 0.003$ for two-stopover species, which included a total of 30 linear regressions per specie (Figure 1).

\section{Results}

3.1. Madison County (Central NY). We found that of the total 195 species used within this dataset from eBird sightings from 2010 to 2015,35 species (18\% of all species included) showed some alteration in their migration timing or experienced significantly colder or warmer temperatures during their migration. Of these affected species, 24 of one-stopover species were long-distance migrants (68\% of affected species and $12 \%$ of all species included), and 5 of two-stopover species were long-distance migrants (14\% of the affected species and 


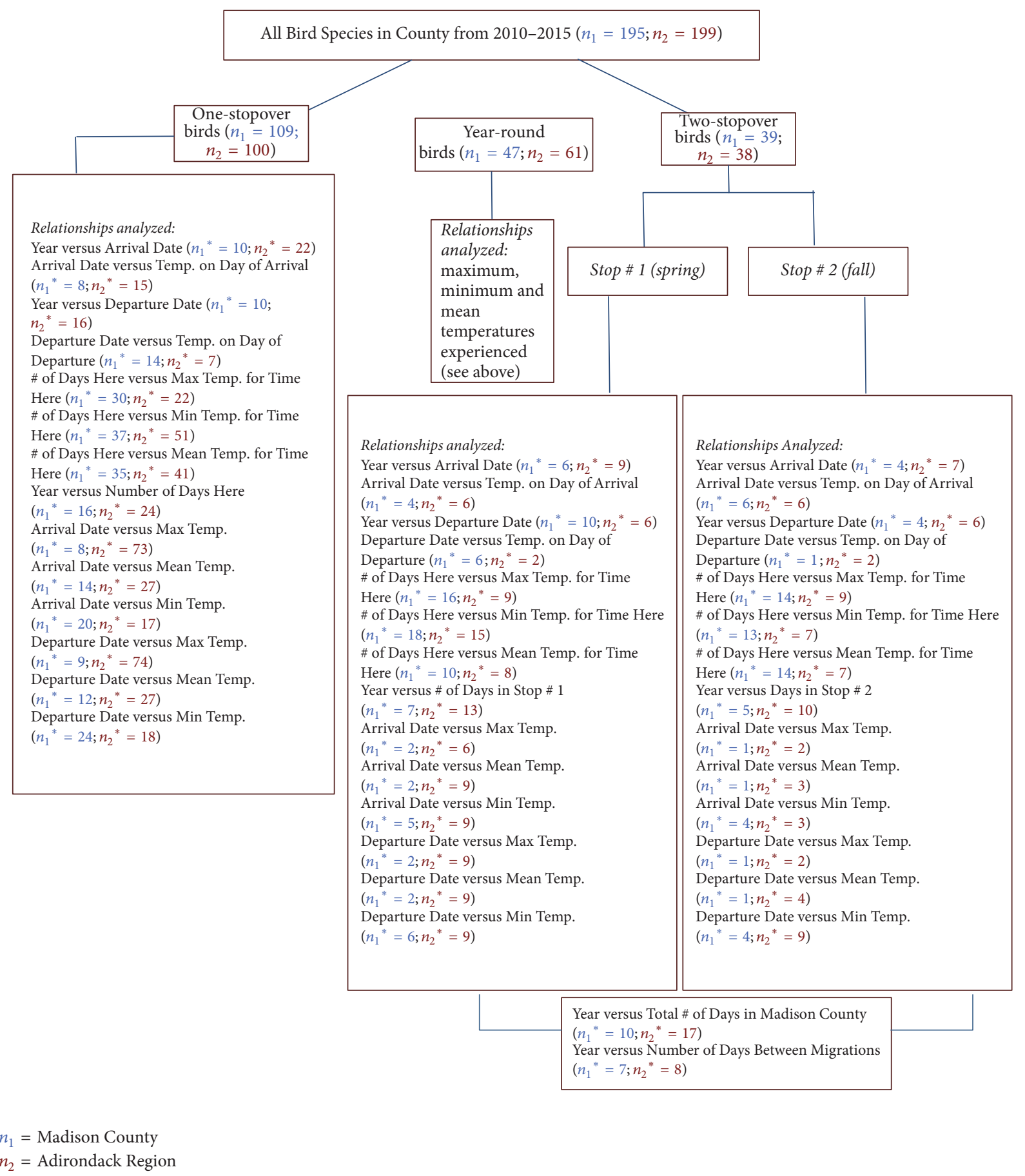

FIGURE 1: Graphical depiction of our experimental design including two New York State areas, each of which have bird species that were classified into resident, one stopover, or two stopover. After classifying each species, we looked at different correlations between migration timing, stopover timing, and relationships therein correlated with historical temperatures in the area.

$2.6 \%$ of all species included). $77 \%$ of the affected one-stopover species experienced significantly colder conditions upon arrival to breeding grounds and $66 \%$ of the affected twostopover species experienced significantly colder conditions while on stopover in Madison County. The majority of onestopover affected species were passerines (56\%), followed by $14 \%$ of the affected species classified as shorebirds, and $8 \%$ as waterfowl. For the affected two-stopover species, 39\% of these were waterfowl, while the other $46 \%$ was equally divided between shorebirds and passerines (Tables 1 and 2). We also found that birds that resided in Madison County year-round from 2010 to 2015 did not experience significant changes in minimum $(p=0.25)$, mean $(p=0.14)$, and maximum temperatures $(p=0.24)$ during those years. 
TABLE 1: Migration timing changes and significant environmental temperature changes experienced by species showing a one-stopover migration strategy through Madison County. Migration patterns were determined using data from the Cornell lab of ornithology and Zuckerberg et al. [23].

\begin{tabular}{|c|c|c|c|c|c|}
\hline Correlation & Species common name & $p$ value & Pattern & Type of bird & Migration pattern \\
\hline Year versus arrival date & Stilt Sandpiper & 0.002 & Earlier & Shorebird & Long distance \\
\hline Year versus departure date & Orchard Oriole & 0.003 & Later & Passerine & Long distance \\
\hline $\begin{array}{l}\text { Departure date versus temperature on } \\
\text { day of departure }\end{array}$ & Wood Thrush & 0.006 & Colder & Passerine & Long distance \\
\hline \multirow{3}{*}{$\begin{array}{l}\text { Number of days in Madison County } \\
\text { versus maximum temperature for time in } \\
\text { Madison County }\end{array}$} & American Woodcock & 0.003 & Warmer & Shorebird & Short distance \\
\hline & Cackling Goose & 0.006 & Warmer & Waterfowl & Long distance \\
\hline & Bank Swallow & 0.004 & Colder & Passerine & Long distance \\
\hline \multirow{2}{*}{$\begin{array}{l}\text { Number of days in Madison County } \\
\text { versus minimum temperature for time in } \\
\text { Madison County }\end{array}$} & Double-Crested Cormorant & 0.007 & Colder & Waterfowl & Medium distance \\
\hline & Peregrine Falcon & 0.004 & Colder & Raptor & Long distance \\
\hline \multirow{10}{*}{$\begin{array}{l}\text { Number of days in Madison County } \\
\text { versus mean temperature for time in } \\
\text { Madison County }\end{array}$} & Red-Shouldered Hawk & 0.003 & Colder & Raptor & Short distance \\
\hline & Common Redpoll & 0.005 & Warmer & Passerine & Long distance \\
\hline & Double-Crested Cormorant & $<0.0001$ & Colder & Waterfowl & Medium distance \\
\hline & Glaucous Gull & 0.004 & Warmer & Shorebird & Long distance \\
\hline & Iceland Gull & 0.006 & Warmer & Shorebird & Long distance \\
\hline & Northern Shrike & 0.002 & Warmer & Passerine & Long distance \\
\hline & Red-Winged Blackbird & 0.003 & Colder & Passerine & Short distance \\
\hline & Snow Bunting & 0.001 & Warmer & Passerine & Long distance \\
\hline & Turkey Vulture & $<0.0001$ & Colder & Vulture & Short distance \\
\hline & Yellow-Bellied Sapsucker & 0.001 & Colder & Woodpecker & Short distance \\
\hline $\begin{array}{l}\text { Year versus number of days in Madison } \\
\text { County }\end{array}$ & Orchard Oriole & 0.002 & $\begin{array}{l}\text { More days } \\
\text { here }\end{array}$ & Passerine & Long distance \\
\hline \multirow{3}{*}{$\begin{array}{l}\text { Arrival date versus maximum } \\
\text { temperature for time in Madison County }\end{array}$} & Black-Billed Cuckoo & 0.004 & Colder & Cuckoo & Long distance \\
\hline & Pine Warbler & 0.001 & Colder & Passerine & Short distance \\
\hline & Blackburnian Warbler & 0.007 & Colder & Passerine & Long distance \\
\hline \multirow{4}{*}{$\begin{array}{l}\text { Arrival date versus minimum } \\
\text { temperature for time in Madison County }\end{array}$} & Magnolia Warbler & $<0.0001$ & Colder & Passerine & Long distance \\
\hline & Semipalmated Sandpiper & 0.004 & Colder & Shorebird & Long distance \\
\hline & Veery & 0.003 & Colder & Passerine & Long distance \\
\hline & Willow Flycatcher & 0.006 & Colder & Passerine & Long distance \\
\hline $\begin{array}{l}\text { Arrival date versus mean temperature for } \\
\text { time in Madison County }\end{array}$ & Willow Flycatcher & 0.007 & Colder & Passerine & Long distance \\
\hline \multirow{3}{*}{$\begin{array}{l}\text { Departure date versus maximum } \\
\text { temperature for time in Madison County }\end{array}$} & Black-Billed Cuckoo & 0.004 & Colder & Cuckoo & Long distance \\
\hline & Pine Warbler & 0.001 & Colder & Passerine & Short distance \\
\hline & Magnolia Warbler & $<0.001$ & Colder & Passerine & Long distance \\
\hline \multirow{3}{*}{$\begin{array}{l}\text { Departure date versus minimum } \\
\text { temperature for time in Madison County }\end{array}$} & Semipalmated Sandpiper & 0.002 & Colder & Shorebird & Long distance \\
\hline & Veery & 0.003 & Colder & Passerine & Long distance \\
\hline & Willow Flycatcher & 0.007 & Colder & Passerine & Long distance \\
\hline $\begin{array}{l}\text { Departure date versus mean temperature } \\
\text { for time in Madison County }\end{array}$ & Willow Flycatcher & 0.006 & Colder & Passerine & Long distance \\
\hline
\end{tabular}

The species which showed repeated significant differences in migration timing and thermal regime experienced within our study included the black-billed Cuckoo, the Magnolia Warbler, the Orchard Oriole, the Semipalmated Sandpiper, the Veery, the Willow Flycatcher, the Common Loon, and the Green-Winged Teal (Tables 1 and 2). All of these species of birds are long-distance migrants, except for the Common Loon (Tables 1 and 2).
3.2. Essex and Franklin Counties (Adirondack Region). Of the total 199 species used within this data set from eBird sightings from 2010 to 2015, 43 species (22\% of all species included) showed some alteration in their migration timing or experienced significantly colder or warmer temperatures during their migration. Of these affected species, 12 of one-stopover species were long-distance migrants $(28 \%$ of affected species and $6 \%$ of all species included), and 10 of 
TABLE 2: Migration timing changes and significant environmental temperature changes experienced by species showing a two-stopover migration strategy through Madison County. Migration patterns were determined using data from the Cornell lab of ornithology and Zuckerberg et al. [23].

\begin{tabular}{|c|c|c|c|c|c|}
\hline Correlation & Species common name & $p$ value & Pattern & Type of bird & Migration pattern \\
\hline $\begin{array}{l}\text { Spring departure date versus temperature } \\
\text { on day of spring departure }\end{array}$ & Bufflehead & 0.002 & Warmer & Waterfowl & Medium distance \\
\hline \multirow{6}{*}{$\begin{array}{l}\text { Number of days in Madison County } \\
\text { during spring versus maximum } \\
\text { temperature for spring time in Madison } \\
\text { County } \\
\text { Number of days in Madison County } \\
\text { during spring migration versus minimum } \\
\text { temperature for time in Madison County } \\
\text { during spring migration }\end{array}$} & Greater Yellowlegs & 0.003 & Warmer & Shorebird & Long distance \\
\hline & Lesser Black-Backed Gull & 0.003 & Warmer & Shorebird & Long distance \\
\hline & Horned Grebe & 0.001 & Colder & Waterfowl & Long distance \\
\hline & Gadwall & 0.002 & Colder & Waterfowl & Long distance \\
\hline & Rusty Blackbird & 0.003 & Colder & Passerine & Short distance \\
\hline & White-Crowned Sparrow & 0.001 & Colder & Passerine & Medium distance \\
\hline $\begin{array}{l}\text { Number of days in Madison County } \\
\text { during fall migration versus minimum } \\
\text { temperature for time in Madison County }\end{array}$ & Horned Lark & 0.002 & Colder & Passerine & Short distance \\
\hline $\begin{array}{l}\text { Number of days in Madison County } \\
\text { during fall migration versus mean } \\
\text { temperature for time in Madison County }\end{array}$ & Common Loon & 0.002 & Colder & Shorebird & Short distance \\
\hline \multirow{2}{*}{$\begin{array}{l}\text { Year versus number of days in fall } \\
\text { stopover }\end{array}$} & Common Loon & 0.003 & More days & Waterfowl & Short distance \\
\hline & Green-Winged Teal & 0.002 & More days & Waterfowl & Medium distance \\
\hline \multirow{2}{*}{$\begin{array}{l}\text { Year versus total number of days in } \\
\text { Madison County }\end{array}$} & Green-Winged Teal & 0.001 & More days & Waterfowl & Medium distance \\
\hline & Semipalmated Plover & 0.001 & More days & Shorebird & Long distance \\
\hline
\end{tabular}

two-stopover species were long-distance migrants $(23 \%$ of the affected species and 5\% of all species included). $97 \%$ of affected one-stopover species experienced significantly colder conditions upon arriving to breeding grounds in the Adirondack region. Similarly, 70\% of all affected twostopover species experienced significantly colder conditions during stopover in this region. Of the affected one-stopover species, $58 \%$ were passerines and $23 \%$ were shorebirds. Similarly, of the affected two-stopover species, $50 \%$ were passerines, $29 \%$ were waterfowl, and $14 \%$ were shorebirds (Tables 3 and 4). Birds that resided in the Adirondack regions year-round from 2010 to 2015 experienced lower maximum temperatures $(p=0.04)$ and lower mean temperatures $(p=$ $0.08)$ during those years. Minimum temperatures did not change across 2010-2015 ( $p=0.42)$.

The species which were most affected within our study for this region include the American Kestrel, Black-Crowned Night-Heron, Double-Crested Cormorant, Eastern Phoebe, Hermit Thrush, Ruby-Crowned Kinglet, Savannah Sparrow, Warbling Vireo, Yellow-bellied Sapsucker, the Horned Lark, and the Northern Shrike (Tables 3 and 4). All of these species of birds are long-distance migrants, except for the BlackCrowned Night-Heron, Eastern Phoebe, and Hermit Thrush (Tables 3 and 4).

Of considerable importance is one vulnerable-listed species included within our study, the Rusty Blackbird, and one species listed as near-threatened, the Semipalmated Sandpiper. The Rusty Blackbird is a short-distance migrant, while the Semipalmated Sandpiper is a long-distance migrant through the NY state area. Both of these species experienced significantly colder conditions during stopover in the NY area.

\section{Discussion}

Species seem to be affected by a hierarchy of abiotic factors, with temperature being the most important factor, followed by humidity, and then by resources available in their local habitat; bird range shifts have been shown to follow this simple hierarchy [32]. Because of this we looked at bird migration timing through the state of New York to determine (1) species that have altered the timing of migration, (2) whether recently arrived or departing species are experiencing significantly different temperature regimes than they normally would, and (3) how long birds that are breeding or migrating through NY are staying in these counties. In order to use the most widely available data to track changing migration timing, we used the citizen science database, eBird, to correlate migration timing of birds through a central New York county and selected Adirondack region, with temperature changes across 2010-2015. The link between phenological advancement due to climate change and bird migration has been widely examined. While some studies show that species are arriving earlier in recent years or in warmer years [33-35], others have seen no pattern of alteration in migration timing [36-38]. The two largest datasets including large geographical regions looking at migration timing found that about $40-50 \%$ of arrival dates are shifting to earlier dates, and only $2 \%$ showed significantly later arrivals $[39,40]$. Our findings are similar to the previously established link between phenology and changes in migration timing. That is, we see some species arriving earlier, departing later, and staying in each county for more days each year (Tables 1-4). Additionally, we also found that a large percentage of the species that seemed to be affected by either migration timing or temperatures in their breeding 
TABLE 3: Migration timing changes and significant environmental temperature changes experienced by species showing a one-stopover migration strategy through Essex and Franklin counties in the Adirondack region. Migration patterns were determined using data from the Cornell lab of ornithology and Zuckerberg et al. [23].

\begin{tabular}{|c|c|c|c|c|c|}
\hline Correlation & Species common name & $p$ value & Pattern & Type of bird & $\begin{array}{l}\text { Migration } \\
\text { pattern }\end{array}$ \\
\hline $\begin{array}{l}\text { Arrival date versus temperature on day of } \\
\text { arrival }\end{array}$ & $\begin{array}{l}\text { Black-Throated Green } \\
\text { Warbler }\end{array}$ & 0.007 & Colder & Passerine & Long distance \\
\hline Year versus departure date & Eastern Phoebe & 0.007 & Later & Passerine & $\begin{array}{l}\text { Short } \\
\text { distance }\end{array}$ \\
\hline \multirow[t]{6}{*}{$\begin{array}{l}\text { Number of days in Essex and Franklin } \\
\text { counties versus maximum temperature } \\
\text { for time here }\end{array}$} & Common Grackle & 0.001 & Warmer & Passerine & $\begin{array}{l}\text { Short } \\
\text { distance }\end{array}$ \\
\hline & Bank Swallow & $<0.001$ & Colder & Passerine & Long distance \\
\hline & American Kestrel & 0.003 & Colder & Shorebird & $\begin{array}{l}\text { Short } \\
\text { distance }\end{array}$ \\
\hline & $\begin{array}{l}\text { Black-Crowned } \\
\text { Night-Heron }\end{array}$ & 0.005 & Colder & Shorebird & $\begin{array}{l}\text { Short } \\
\text { distance }\end{array}$ \\
\hline & Brown Thrasher & 0.007 & Colder & Passerine & $\begin{array}{l}\text { Short } \\
\text { distance }\end{array}$ \\
\hline & Chipping Sparrow & 0.005 & Colder & Passerine & Long distance \\
\hline \multirow{14}{*}{$\begin{array}{l}\text { Number of days in Essex and Franklin } \\
\text { counties versus minimum temperature } \\
\text { for time here }\end{array}$} & Double-Crested Cormorant & $<0.001$ & Colder & Waterfowl & $\begin{array}{l}\text { Medium } \\
\text { distance }\end{array}$ \\
\hline & Hermit Thrush & 0.002 & Colder & Passerine & $\begin{array}{c}\text { Short } \\
\text { distance }\end{array}$ \\
\hline & Indigo Bunting & 0.007 & Colder & Passerine & Long distance \\
\hline & Ruby-Crowned Kinglet & 0.002 & Colder & Passerine & $\begin{array}{c}\text { Short } \\
\text { distance }\end{array}$ \\
\hline & Sanderling & 0.007 & Colder & Shorebird & Long distance \\
\hline & Savannah Sparrow & 0.001 & Colder & Passerine & $\begin{array}{l}\text { Short } \\
\text { distance }\end{array}$ \\
\hline & Yellow-Bellied Sapsucker & $<0.001$ & Colder & Woodpecker & $\begin{array}{l}\text { Short } \\
\text { distance }\end{array}$ \\
\hline & Double-Crested Cormorant & $<0.001$ & Colder & Waterfowl & $\begin{array}{l}\text { Medium } \\
\text { distance }\end{array}$ \\
\hline & American Kestrel & 0.007 & Colder & Shorebird & $\begin{array}{c}\text { Short } \\
\text { distance }\end{array}$ \\
\hline & Belted Kingfisher & 0.001 & Colder & Kingfisher & $\begin{array}{c}\text { Short } \\
\text { distance }\end{array}$ \\
\hline & $\begin{array}{l}\text { Black-Crowned } \\
\text { Night-Heron }\end{array}$ & 0.002 & Colder & Shorebird & $\begin{array}{c}\text { Short } \\
\text { distance }\end{array}$ \\
\hline & Brown-Headed Cowbird & 0.007 & Colder & Passerine & $\begin{array}{c}\text { Short } \\
\text { distance }\end{array}$ \\
\hline & Great Blue Heron & 0.001 & Colder & Shorebird & $\begin{array}{c}\text { Short } \\
\text { distance }\end{array}$ \\
\hline & Green Heron & 0.002 & Colder & Shorebird & Long distance \\
\hline \multirow{7}{*}{$\begin{array}{l}\text { Number of days in Essex and Franklin } \\
\text { counties versus mean temperature for } \\
\text { time here }\end{array}$} & Hermit Thrush & $<0.001$ & Colder & Passerine & $\begin{array}{c}\text { Short } \\
\text { distance }\end{array}$ \\
\hline & Lincoln’s Sparrow & 0.004 & Colder & Passerine & Long distance \\
\hline & Marsh Wren & 0.003 & Colder & Passerine & $\begin{array}{c}\text { Short } \\
\text { distance }\end{array}$ \\
\hline & Merlin & 0.003 & Colder & Raptor & Long distance \\
\hline & Ruby-Crowned Kinglet & $<0.001$ & Colder & Passerine & $\begin{array}{c}\text { Short } \\
\text { distance }\end{array}$ \\
\hline & $\begin{array}{l}\text { Ruby-Throated } \\
\text { Hummingbird }\end{array}$ & 0.003 & Colder & Hummingbird & Long distance \\
\hline & Savannah Sparrow & $<0.001$ & Colder & Passerine & $\begin{array}{c}\text { Short } \\
\text { distance }\end{array}$ \\
\hline
\end{tabular}


TABLE 3: Continued.

\begin{tabular}{|c|c|c|c|c|c|}
\hline Correlation & Species common name & $p$ value & Pattern & Type of bird & $\begin{array}{l}\text { Migration } \\
\text { pattern }\end{array}$ \\
\hline & Winter Wren & 0.006 & Colder & Passerine & $\begin{array}{c}\text { Short } \\
\text { distance }\end{array}$ \\
\hline & Wood Duck & 0.007 & Colder & Waterfowl & $\begin{array}{c}\text { Short } \\
\text { distance }\end{array}$ \\
\hline & Yellow-Bellied Sapsucker & $<0.001$ & Colder & Woodpecker & $\begin{array}{l}\text { Short } \\
\text { distance }\end{array}$ \\
\hline $\begin{array}{l}\text { Year versus number of days in Essex and } \\
\text { Franklin counties }\end{array}$ & Red-Eyed Vireo & 0.001 & $\begin{array}{l}\text { More days } \\
\text { here }\end{array}$ & Passerine & Long distance \\
\hline \multirow{2}{*}{$\begin{array}{l}\text { Arrival date versus maximum } \\
\text { temperature for time in Essex and } \\
\text { Franklin counties }\end{array}$} & $\begin{array}{l}\text { Black-Crowned } \\
\text { Night-Heron }\end{array}$ & 0.006 & Colder & Shorebird & $\begin{array}{c}\text { Short } \\
\text { distance }\end{array}$ \\
\hline & Warbling Vireo & 0.005 & Colder & Passerine & Long distance \\
\hline $\begin{array}{l}\text { Arrival date versus minimum temp for } \\
\text { time in Essex and Franklin counties }\end{array}$ & Eastern Phoebe & 0.007 & Colder & Passerine & $\begin{array}{c}\text { Short } \\
\text { distance }\end{array}$ \\
\hline $\begin{array}{l}\text { Arrival date versus mean temperature for } \\
\text { time in Essex and Franklin counties }\end{array}$ & Cliff Swallow & 0.002 & Colder & Passerine & Long distance \\
\hline \multirow{2}{*}{$\begin{array}{l}\text { Departure date versus maximum } \\
\text { temperature for time in Essex and } \\
\text { Franklin counties }\end{array}$} & $\begin{array}{l}\text { Black-Crowned } \\
\text { Night-Heron }\end{array}$ & 0.005 & Colder & Shorebird & $\begin{array}{c}\text { Short } \\
\text { distance }\end{array}$ \\
\hline & Warbling Vireo & 0.006 & Colder & Passerine & Long distance \\
\hline $\begin{array}{l}\text { Departure date versus minimum } \\
\text { temperature for time in Essex and } \\
\text { Franklin counties }\end{array}$ & Eastern Phoebe & 0.007 & Colder & Passerine & $\begin{array}{c}\text { Short } \\
\text { distance }\end{array}$ \\
\hline
\end{tabular}

grounds or during stopover were long-distance migrants. We also, surprisingly, found that the thermal variations most bird species were experiencing in the state of New York in 2010-2015 are colder, rather than warmer, temperatures (Tables 1-4).

Our data suggests that many migratory birds through the NY area over the years of 2010-2015 have experienced significantly colder or warmer temperatures, regardless of rate of warming in each county. Physiologically, either extreme in temperature will be challenging for a bird during breeding or on stopover from migration, which, then, begs the question: would temperature increases or decreases upon arrival or departure be a worse physiological challenge for migrating birds? For temperate migratory birds, which have evolved to withstand relatively wide temperature fluctuations, increases in air temperature will likely cause body temperature to be elevated. This will be especially problematic for individuals traveling long distances; flying already exerts endogenous heat, and any increases in air temperature will further the heat load on the migrating bird, possibly causing further physiological injury and stress. In previous experiments, Garden Warblers exposed to high environmental temperatures were shown to not be able to regain much migratory body mass during the stopover period, which is the main objective for migratory birds, likely due to the increases of energy expenditure associated with the costs of thermoregulating and maintaining water balance [41]. As a result, the ability to regain body mass during stopover is an important factor in a bird's ability to successfully continue its migration or to breed, and those individuals who cannot do this are more vulnerable to the physiological challenges of migration. At worst, extreme heat wave events have occasionally led to catastrophic avian mortality [42].

Birds may also face physiological challenges when the temperature at breeding grounds significantly decreases. In response to environmental variation, individuals can make plastic changes to their physiology to maximize survival and fitness. For example, in response to certain cues, such as acclimation to cold, molting, migration, or breeding, phenotypic plasticity of organ size can account for significant increases or reductions in energy expenditure [43]. Phenotypic flexibility in aerobic metabolism is likely a trait of utmost importance for endotherms dealing with thermally challenging environmental conditions [44]. Cold temperature extremes are a strong selective pressure driving metabolic adaptation for birds so that $60 \%$ of bird species overwintering in North America have limited ranges that are directly correlated with mean minimum January temperature $[44,45]$. Unseasonable colder temperatures occurring soon after migrants arrive to breeding grounds in the spring have also caused mass mortality events [46], not just due to environmentally colder temperatures that cause an increase in metabolic rates due to shivering, but also because of the loss of food supply in snow and icy conditions [46]. For example, White Storks, Ciconia ciconia, delayed arrival to breeding ground during cold years, but their breeding success was not affected [47]. However, most migrants have increased muscle mass from migrating, which allows for increased ability to thermoregulate in colder conditions [48].

It, therefore, seems that increasing temperatures may be a more deleterious environmental challenge for migrating birds than decreasing temperatures. Since the majority of 
TABLE 4: Migration timing changes and significant environmental temperature changes experienced by species showing a two-stopover migration strategy through Essex and Franklin counties in the Adirondack region. Migration patterns were determined using data from the Cornell lab of ornithology and Zuckerberg et al. [23].

\begin{tabular}{|c|c|c|c|c|c|}
\hline Correlation & $\begin{array}{l}\text { Species } \\
\text { common } \\
\text { name }\end{array}$ & $p$ value & Pattern & Type of bird & $\begin{array}{l}\text { Migration } \\
\text { pattern }\end{array}$ \\
\hline Year versus spring arrival date & $\begin{array}{l}\text { Tennessee } \\
\text { Warbler }\end{array}$ & 0.001 & Earlier & Passerine & Long distance \\
\hline $\begin{array}{l}\text { Spring arrival date versus temperature on } \\
\text { day of spring arrival }\end{array}$ & $\begin{array}{l}\text { Common } \\
\text { Nighthawk }\end{array}$ & 0.002 & Colder & Nightjar & Long distance \\
\hline \multirow{2}{*}{$\begin{array}{l}\text { Number of days in Essex and Franklin } \\
\text { counties during spring versus maximum } \\
\text { temperature for spring time in Essex and } \\
\text { Franklin Counties }\end{array}$} & Horned Lark & 0.003 & Warmer & Passerine & $\begin{array}{c}\text { Short } \\
\text { distance }\end{array}$ \\
\hline & $\begin{array}{l}\text { Northern } \\
\text { Shrike }\end{array}$ & 0.003 & Warmer & Passerine & Long distance \\
\hline \multirow{2}{*}{$\begin{array}{l}\text { Number of days in Essex and Franklin } \\
\text { counties during spring migration versus } \\
\text { minimum temperature for time in Essex } \\
\text { and Franklin counties during spring } \\
\text { migration }\end{array}$} & Bufflehead & 0.002 & Colder & Waterfowl & $\begin{array}{l}\text { Medium } \\
\text { distance }\end{array}$ \\
\hline & $\begin{array}{l}\text { Northern } \\
\text { Pintail }\end{array}$ & 0.002 & Colder & Waterfowl & $\begin{array}{c}\text { Short } \\
\text { distance }\end{array}$ \\
\hline $\begin{array}{l}\text { Spring departure date versus mean } \\
\text { temperature for time in Essex and } \\
\text { Franklin counties }\end{array}$ & $\begin{array}{l}\text { Northern } \\
\text { Shrike }\end{array}$ & 0.003 & Colder & Passerine & Long distance \\
\hline $\begin{array}{l}\text { Fall arrival date versus temperature on } \\
\text { day of fall arrival }\end{array}$ & $\begin{array}{l}\text { Bay-Breasted } \\
\text { Warbler }\end{array}$ & 0.001 & Colder & Passerine & Long distance \\
\hline \multirow{2}{*}{$\begin{array}{l}\text { Fall departure date versus temperature on } \\
\text { day of fall departure }\end{array}$} & $\begin{array}{l}\text { Cape May } \\
\text { Warbler }\end{array}$ & 0.002 & Colder & Passerine & Long distance \\
\hline & $\begin{array}{l}\text { Greater } \\
\text { Yellowlegs }\end{array}$ & 0.001 & Colder & Shorebird & Long distance \\
\hline $\begin{array}{l}\text { Number of days in Essex and Franklin } \\
\text { counties during fall migration versus } \\
\text { maximum temperature for time in Essex } \\
\text { and Franklin counties }\end{array}$ & Horned Lark & $<0.001$ & Warmer & Passerine & $\begin{array}{c}\text { Short } \\
\text { distance }\end{array}$ \\
\hline $\begin{array}{l}\text { Year versus number of days in spring } \\
\text { stopover }\end{array}$ & Lesser Scaup & 0.001 & More days & Waterfowl & Long distance \\
\hline $\begin{array}{l}\text { Year versus number of days in fall } \\
\text { stopover }\end{array}$ & $\begin{array}{l}\text { Solitary } \\
\text { Sandpiper }\end{array}$ & 0.003 & More days & Shorebird & Long distance \\
\hline $\begin{array}{l}\text { Year versus total number of days in Essex } \\
\text { and Franklin counties }\end{array}$ & $\begin{array}{l}\text { Horned } \\
\text { Grebe }\end{array}$ & 0.002 & More days & Waterfowl & Long distance \\
\hline
\end{tabular}

birds that were affected by temperature changes in 2010-2015 in the state of NY were facing decreasing temperatures, regardless of warming rate previously predicted, we may assume that these birds that are either summering/breeding or on stopover in NY are physiologically well suited to deal with colder temperatures. However, while they may be able to withstand low temperatures effectively, the question remains as to whether appropriate resources are available for them at the time of arrival or departure, to recover from migration.

Many studies have pointed to flexibility and alteration in migration timing of short-distance migrants [10] and have determined that long-distance migrants are likely not shifting migratory timing, thus putting them in danger of population declines $[17,18]$. Although long-distance migrants seem to be under endogenous control for the onset of spring migration [16], our study highlights that many of the species that were significantly affected by temperature changes and those that have altered their migration timing through the state of New
York were long-distance migrants (Tables 1-4). Tøttrup et al. [13] concluded that local spring temperatures in migratory route are the best predictors of bird phenology, despite whether the migrating specie is a short- or long-distance migrant. Similar patterns of shift in migratory strategy for long-distance migrants have been documented for birds on Helgoland [33] and birds in Scandinavia and southern Italy [12].

Our study shows that several species of migrating birds have altered their migration timing and are facing significantly different temperature regimes while breeding or on migration stopover in the NY state area, whereas yearround resident birds may not be experiencing such drastic temperature changes across the years of 2010-2015. Many of the species affected are long-distance migrants, and those species that face increases in temperature may be more vulnerable to deleterious physiological challenges than those facing decreasing temperature. 


\section{Conflicts of Interest}

The authors have no conflicts of interest to declare.

\section{Acknowledgments}

The authors would like to thank Dr. Ahmet Ay for his advice on statistical analysis and John Pumilio for sharing his expertise on migratory birds with them.

\section{References}

[1] A. Jentsch, J. Kreyling, and C. Beierkuhnlein, "A new generation of climate-change experiments: events, not trends," Frontiers in Ecology and the Environment, vol. 5, no. 7, pp. 365-374, 2007.

[2] M. J. Angilletta Jr., "Looking for answers to questions about heat stress: researchers are getting warmer," Functional Ecology, vol. 23, no. 2, pp. 231-232, 2009.

[3] S. L. Chown, A. A. Hoffmann, T. N. Kristensen, M. J. Angilletta Jr., N. C. Stenseth, and C. Pertoldi, "Adapting to climate change: a perspective from evolutionary physiology," Climate Research, vol. 43, no. 1, pp. 3-15, 2010.

[4] F. Seebacher and C. E. Franklin, "Determining environmental causes of biological effects: the need for a mechanistic physiological dimension in conservation biology," Philosophical Transactions of the Royal Society of London B: Biological Sciences, vol. 367, no. 1596, pp. 1607-1614, 2012.

[5] H.-C. Schaefer, W. Jetz, and K. Böhning-Gaese, "Impact of climate change on migratory birds: Community reassembly versus adaptation," Global Ecology and Biogeography, vol. 17, no. 1, pp. 38-49, 2008.

[6] P. A. Cotton, "Avian migration phenology and global climate change," Proceedings of the National Academy of Sciences of the United States of America, vol. 100, no. 21, pp. 12219-12222, 2003.

[7] A. H. Hurlbert and Z. Liang, "Spatiotemporal variation in avian migration phenology: citizen science reveals effects of climate change," PLoS ONE, vol. 7, no. 2, Article ID e31662, 2012.

[8] J. A. Gill, J. A. Alves, W. J. Sutherland, G. F. Appleton, P. M. Potts, and T. G. Gunnarsson, "Why is timing of bird migration advancing when individuals are not?" Proceedings of the Royal Society of London B, vol. 281, no. 1774, Article ID 20132161, 2013.

[9] O. Gordo, "Why are bird migration dates shifting? A review of weather and climate effects on avian migratory phenology," Climate Research, vol. 35, no. 1-2, pp. 37-58, 2007.

[10] F. Pulido, "Phenotypic changes in spring arrival: Evolution, phenotypic plasticity, effects of weather and condition," Climate Research, vol. 35, no. 1-2, pp. 5-23, 2007.

[11] A. D. Smith and S. R. McWilliams, "What to do when stopping over: behavioral decisions of a migrating songbird during stopover are dictated by initial change in their body condition and mediated by key environmental conditions," Behavioral Ecology, vol. 25, no. 6, pp. 1423-1435, 2014.

[12] N. Jonzén, A. Lindén, T. Ergon et al., "Rapid advance of spring arrival dates in long-distance migratory birds," Science, vol. 312, no. 5782, pp. 1959-1961, 2006.

[13] A. P. Tøttrup, K. Rainio, T. Coppack, E. Lehikoinen, C. Rahbek, and K. Thorup, "Local temperature fine-tunes the timing of spring migration in birds," Integrative and Comparative Biology, 2010.
[14] E. Knudsen, A. Lindén, C. Both et al., "Challenging claims in the study of migratory birds and climate change," Biological Reviews, vol. 86, no. 4, pp. 928-946, 2011.

[15] C. Gómez, N. J. Bayly, D. R. Norris et al., "Fuel loads acquired at a stopover site influence the pace of intercontinental migration in a boreal songbird," Scientific Reports, vol. 7, no. 1, article 3405, 2017.

[16] Z. Végvári, V. Bókony, Z. Barta, and G. Kovács, "Life history predicts advancement of avian spring migration in response to climate change," Global Change Biology, vol. 16, no. 1, pp. 1-11, 2010.

[17] A. P. Møller, D. Rubolini, and E. Lehikoinen, "Populations of migratory bird species that did not show a phenological response to climate change are declining," Proceedings of the National Academy of Sciences of the United States of America, vol. 105, no. 42, pp. 16195-16200, 2008.

[18] C. Both, C. A. Van Turnhout, R. G. Bijlsma, H. Siepel, A. J. Van Strien, and R. P. Foppen, "Avian population consequences of climate change are most severe for long-distance migrants in seasonal habitats," Proceedings of the Royal Society of London B: Biological Sciences, Article ID rspb20091525, 2009.

[19] P. Tryjanowski, S. Kuźniak, and T. H. Sparks, "What affects the magnitude of change in first arrival dates of migrant birds?" Journal of Ornithology, vol. 146, no. 3, pp. 200-205, 2005.

[20] G. Walther, E. Post, P. Convey et al., "Ecological responses to recent climate change," Nature, vol. 416, no. 6879, pp. 389-395, 2002.

[21] S. C. Trombulak and R. Wolfson, "Twentieth-century climate change in New England and New York, USA," Geophysical Research Letters, vol. 31, no. 19, 2004.

[22] R. Horton, C. Rosenzweig, V. Gornitz, D. Bader, and M. O'Grady, "Climate risk information," Annals of the New York Academy of Sciences, vol. 1196, no. 1, pp. 147-228, 2010.

[23] B. Zuckerberg, A. M. Woods, and W. F. Porter, "Poleward shifts in breeding bird distributions in New York State," Global Change Biology, vol. 15, no. 8, pp. 1866-1883, 2009.

[24] C. L. Catlin-Groves, "The citizen science landscape: from volunteers to citizen sensors and beyond," International Journal of Zoology, Article ID 349630, 2012.

[25] J. L. Dickinson, B. Zuckerberg, and D. N. Bonter, "Citizen science as an ecological research tool: challenges and benefits," Annual Review of Ecology, Evolution and Systematics, vol. 41, pp. 149-172, 2010.

[26] C. Wood, B. Sullivan, M. Iliff, D. Fink, and S. Kelling, "eBird: engaging birders in science and conservation," PLoS biology, vol. 9, no. 12, Article ID e1001220, 2011.

[27] B. L. Sullivan, J. L. Aycrigg, J. H. Barry et al., "The eBird enterprise: an integrated approach to development and application of citizen science," Biological Conservation, vol. 169, pp. 31-40, 2014.

[28] C. B. Cooper, J. Shirk, and B. Zuckerberg, “The invisible prevalence of citizen science in global research: migratory birds and climate change," PLoS ONE, vol. 9, no. 9, Article ID e106508, 2014.

[29] K. Kaufman, Kaufman Field Guide to Birds of North America, Houghton Mifflin Harcourt, USA.

[30] R. T. Peterson, Peterson Field Guide to Birds of Eastern and Central North America, vol. 6, Houghton Mifflin Harcourt, USA, 2010.

[31] J. Rappole, The Avian Migrant: The Biology of Bird Migration, Columbia University Press, NY, USA, 2013. 
[32] A. L. Pigot, I. P. F. Owens, and C. D. L. Orme, "The environmental limits to geographic range expansion in birds," Ecology Letters, vol. 13, no. 6, pp. 705-715, 2010.

[33] O. Hüppop and K. Hüppop, "North Atlantic Oscillation and timing of spring migration in birds," Proceedings of the Royal Society of London B: Biological Sciences, vol. 270, no. 1512, pp. 233-240, 2003.

[34] O. Gordo and J. J. Sanz, "Climate change and bird phenology: a long-term study in the Iberian Peninsula," Global Change Biology, vol. 12, no. 10, pp. 1993-2004, 2006.

[35] D. L. Swanson and J. S. Palmer, "Spring migration phenology of birds in the Northern Prairie region is correlated with local climate change," Journal of Field Ornithology, vol. 80, no. 4, pp. 351-363, 2009.

[36] T. H. Sparks and O. Braslavská, "The effects of temperature, altitude and latitude on the arrival and departure dates of the swallow Hirundo rustica in the Slovak Republic," International Journal of Biometeorology, vol. 45, no. 4, pp. 212-216, 2001.

[37] R. T. Barrett, "The phenology of spring bird migration to north Norway," Bird Study, vol. 49, no. 3, pp. 270-277, 2002.

[38] P. K. Strode, "Implications of climate change for North American wood warblers (Parulidae)," Global Change Biology, vol. 9, no. 8, pp. 1137-1144, 2003.

[39] E. S. A. Lehikoinen, T. H. Sparks, and M. Zalakevicius, "Arrival and departure dates," Advances in Ecological Research, vol. 35, pp. 1-31, 2004.

[40] T. H. Sparks, K. Huber, R. L. Bland et al., "How consistent are trends in arrival (and departure) dates of migrant birds in the UK?" Journal of Ornithology, vol. 148, no. 4, pp. 503-511, 2007.

[41] U. Bauchinger, S. R. McWilliams, and B. Pinshow, "Reduced body mass gain in small passerines during migratory stopover under simulated heat wave conditions," Molecular \& Integrative Physiology, vol. 158, no. 4, pp. 374-381, 2011.

[42] A. E. McKechnie and B. O. Wolf, "Climate change increases the likelihood of catastrophic avian mortality events during extreme heat waves," Biology Letters, vol. 6, no. 2, pp. 253-256, 2010.

[43] T. Piersma and J. A. Van Gils, The Flexible Phenotype: A Body-Centered Integration of Ecology, Physiology, and Behaviour, Oxford University Press, Oxford, UK, 2011.

[44] M. Stager, H. S. Pollock, P. M. Benham, N. D. Sly, J. D. Brawn, and Z. A. Cheviron, "Disentangling environmental drivers of metabolic flexibility in birds: the importance of temperature extremes versus temperature variability," Ecography, vol. 39, no. 8, pp. 787-795, 2016.

[45] D. L. Swanson and T. Garland Jr., "The evolution of high summit metabolism and cold tolerance in birds and its impact on present-day distributions," Evolution, vol. 63, no. 1, pp. 184-194, 2009.

[46] I. Newton, "Weather-related mass-mortality events in migrants," Ibis, vol. 149, no. 3, pp. 453-467, 2007.

[47] P. Tryjanowski, T. H. Sparks, J. Ptaszyk, and J. Kosicki, “Do white storks Ciconia ciconia always profit from an early return to their breeding grounds?" Bird Study, vol. 51, no. 3, pp. 222-227, 2004.

[48] U. Bauchinger and S. R. McWilliams, "Extent of phenotypic flexibility during long-distance flight is determined by tissuespecific turnover rates: a new hypothesis," Journal of Avian Biology, vol. 41, no. 6, pp. 603-608, 2010. 

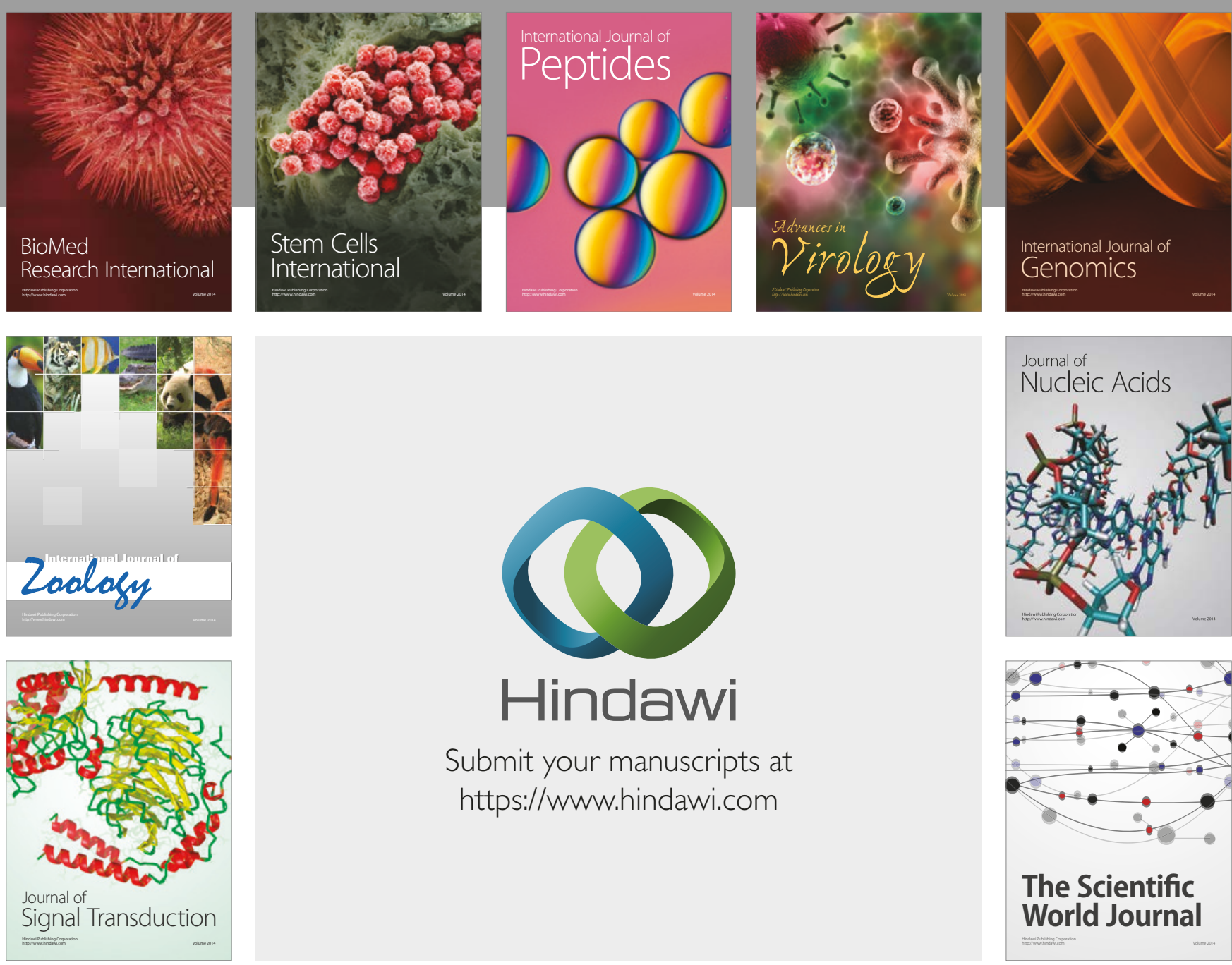

Submit your manuscripts at

https://www.hindawi.com
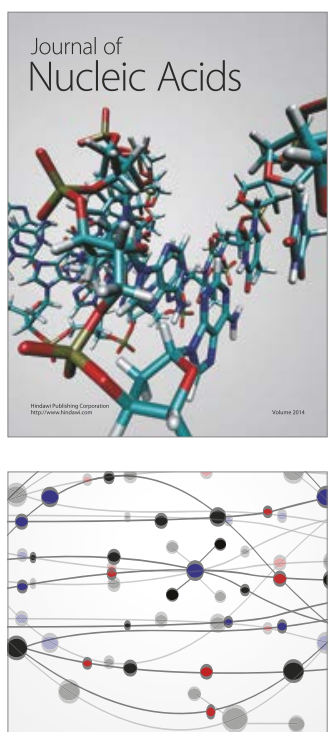

The Scientific World Journal

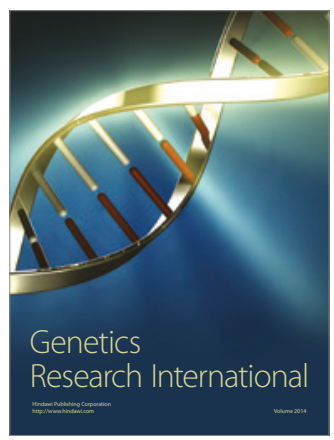

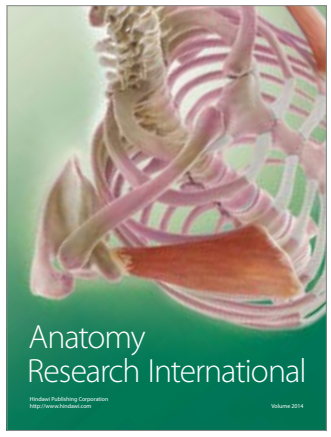

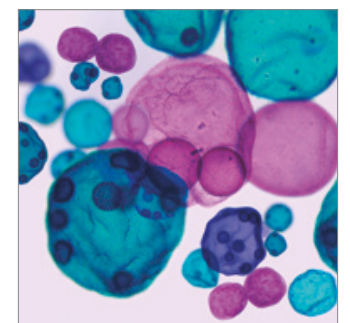

International Journal of Microbiology
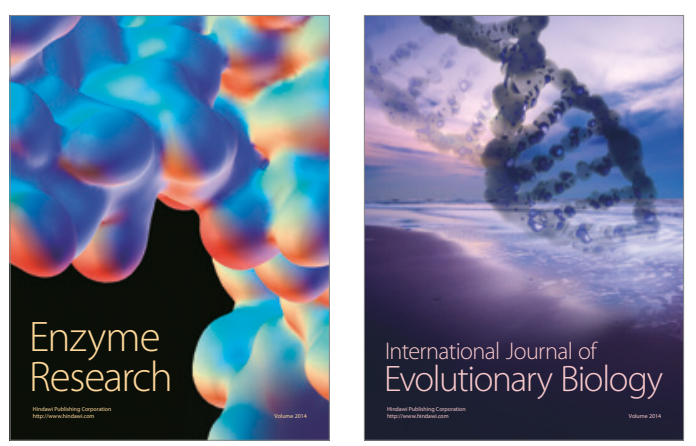
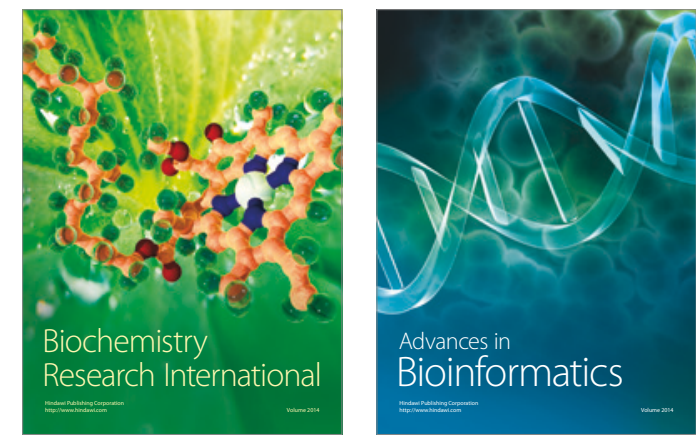

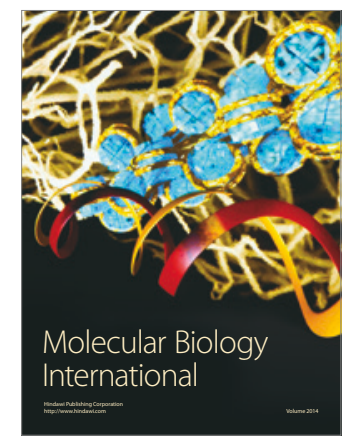

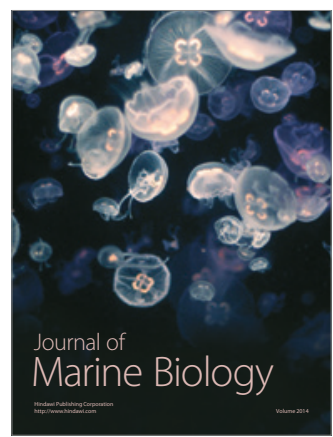

